尼，自覚症状発現率に年歯化傾向をみとめることができ なかったが，これは該集団の平均年龄が，男女 25.5 歳， 女子 24.2 歳ときうめて若いためである。

いわゆる持薬の利用はわなり多く, とくに男子30歳台 の職員に集中する傾向を示したが，遺伝歴の有無とは関 連しなかった。

上記の結果にしたがって，今後，問題者の面接を行な い, 調査表の信頼度, Memory Factor の分析を試及 たいと考えている。

\section{4. いすず自動車鶴見製造所における}

\section{消化器検診について}

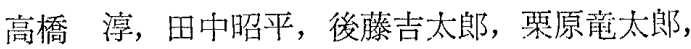
岩崎政明（日大，有賀内科）

上野慶夫（いすず病院衛生管理室）

いすず自動車鶴見製造所の疾病統計よりみた従業員の 羅患傾向は，胃晹疾患が感置についで多く，その生産性 に与える影響は軽視できない問題である。また産業の近 代化に伴ない，その作業性よりきたる，ストレスの発生 は消化機能に与觉る影響も大きいといわれている。以上 の観点から, 従業員の消化器病の実態の把握と適正な管 理が望まれる。よって我々は昭和35年10月, 当工場の胃 集団検誩を行なったので，その成績の概要を報告する。

1）全従業員を対象としたが，作業性及び生産計画等 を勘案し，全員を2班に分割した。今次検診の対象を満 .40歳以上の男女従業員とし，404 名を検診した。

2）検診万法性被検者全員に，(价家族歴，既往歷，嘫 好, 食㥜慣, 自覚症状等を問い, 基礎調查表を作成し, (吅約 5 日間隔にて検便（潜血反応・等生虫卵検查） 3 回 実施，(ツ一般診察（主として腹部触診）（シ胃レントゲ ン間接撮影を行ない，以上の成績を綜合判定し，必要あ りと認められたものに，(精密検診を実施した。

3）検査成績は被検者総員 404 名のらち，異常なし之 認められたもの 254 例 $(62.9 \%)$ ，な几らかの疾患を認め られたもの 150 例 $(37.1 \%)$ であり，これら発見疾忠の 内訳は，胃漬痬 5 例 $(1.2 \%)$ ，胃・十二指腸潰痬 2 例 $(0.5 \%)$ ，十二指腸潰癔 13 例 $(3.2 \%)$ ，罚下垂 72 例 $(17.8 \%)$ ，胆石症 2 例 $(0.5 \%)$ ，胃ポリープ1例，胃炎 40 例 $(9.9 \%)$ ，その他15例 $(3.7 \%)$ であり，各泟例に つい, 職種, 作業環境, 消化器疾患発生率との相関に ついて検討した。

4）発見疾患の検討を行ならとともに，従業員の家族

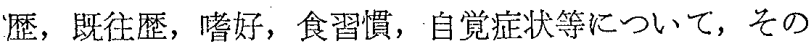
傾向調査を行ない，今後の消化器疾患の管理の資料とし
た。

\section{5. 某染料工場における全血比重の長期観察}

重田定義（麖大衛生公臬衛生）

硫酸銅法による全血比重測定は，その簡易性のゆ克 に，多くの事業場に执いて早くから実施されており，そ の集団検診に招ける価值は広くみとめられているが，某 染料工場の男子従業員全員について, 昭和 29 年以降 7 年 間, のべ13回の全血比重值が得られたので，こ机を中心 として若干の考察を行なった。

全血比重值は，毎年 5 月と10月の 2 回実施する定期健 診から得たものである。

従策員は現場部門之間接部門の二つに大別した。

7 年間に和ける全血比重の平均值は，現場部閉では 1.05405〜1.05554，間接部門では 1.05414〜1.05582の 範图にある。

全血比重の逐年推移について，現場部門之間接部門を 此較した結果は，ほとえどの時期において，現場部門は 間接部門より低い值を示している。また両群ともに全血 比重值に季節変動がみとめられ，春に高く，秋低い相 を示しだ。

さらに全血比重と比体重との関係，全血比重と淽続年 数などについても分析中である。

全血比重は諸種の要因によって変動するので，ただら にその原因を有害作策環境に帰することは危険であら ら。しかしながら現場部門之間接部門との閒のこのよう な相違は，染料工場の現場に有害業務がきわめて多いと いら実情からみて，有害作業条件の要因がある程度はた らいていることを見逃すわけにはいかない。

\section{6. 工場従業員の潜在性遧害の動態分析（3 啹）}

方瀬護国・底中健吉・池田克明・雇藤欣一

（日本鋼管病院健康管理室）

5 年間にわたる多面的集団検診の成績にもとずき，工 場従業員の潜在性障害につき，各種要因之関連つけての 動態分析を実施しつつある。今回は全血比重に関する知 見について報皆する。

1. 4 年間迫及し得た 928 例のう占，初年度に盆血之 判定されたもの 44 例について，第 4 年度に和ける推移を 見ると，貧血の消失したもの 21 例，48\%である。年 齢 階級の低い汪ど，所見消失率の高い傾向がある程度認め られる。

2. 初年度非盆血者 784. 例のうち，4 年度貧血の発現 したもの27例，3.4\% である。年掬階級の高いほど，発 
現率が高いことが認められる。

3. 初年度と 4 年度とにつき全般的に全血此重の推移 を多集検の成續について比較すると，どの年龄層でもわ ずかながら増加の傾向が認められる。年䍅增加に伴なう 全血比重低下の傾向と矛盾するが，管理の効果の現われ と考えられる。

4. 業態の異なる数事業所の40菽以上の男子従業員 計 3423 名の全血比重は, A : 1055.2, B : 1054.7, $\mathrm{C}: 1055.2, \mathrm{D}: 1055.6$ で，その間に多少の差異がある が，とくに年齢的推移の差異が注目される。

5 . 第 2 次検診の受検者 515 例の中, 異常なし 284 例 15.2\%, 要注意 $33.4 \%$, 要治療 $11.4 \%$ であった。 異常確認率が既報より低いのは, 主として判定基準の変 更による。

6. 職層別に, 全血比重と体重標準比とを比较する

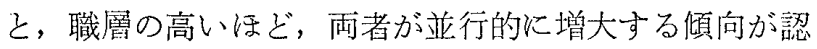
められる。

7. 全血比重の常態値の集団的变動要因として, 年 齢・職層・栄盖等について, 再検討を加え, 既報の知見 を確認した。

\section{7. 工場労働者の尿スクリーニング検査について}

佐藤信一，村川和子（富士電機川崎涪療所） 工場労働者のなかには無自筧に身体的異常をきたして いるものがあって，そのために仕事の能率低下がみられ たり，潜在性疾患が見逃される場合がある。その意味で 第33回産業医学会に招いて, 工場学働者の貧抯の状態を 調査佯告したが，今回は尿のスクリーニング検查によっ てふるい分けられた異常者がぞのようなるのであるかの 検討を試みた。

34年秋に成人病管理の一つとして，40歳以上の全從業 員について, 蛋白, 糖, ウロビリノーゲンの尿検査を行 なったが，その成績は尿蛋白 $5.8 \%$ ，尿糖 $8.9 \%$ ，ウ口 ビリノーゲン $13.5 \%$ の陽性率であった。これより精密 検査を行ならと，かなりの異常者を発見したので，35年 春季健康診断には男子全員の尿スクリーニング検査を行 なった。

被検者は男子 3927 名で, 検査は蛋白, 糖, ウロビリ ノーゲンの3 項目について行なった。検査方法は蛋白, ウロビリノーゲンについては, 磁性皿による spot-test 尿集団検査法を，糖についてはテステープを使用した。 検査による陽性率は蛋白 $3.5 \%$ ，糖 $4.1 \%$, ウ口ビリノ ーゲン $7.8 \%$ であった。これらを年齢別にみると，尿蛋 移は若年者に多く，尿糖は高年者に多く, ウ口ビリノ一
ゲンは各年歯層とも平均してみられた。これら陽性者に ついて秋季健康診断時に再検査を試みたところ,な打陽 性を示すものは，さきの陽性者のらち，尿蛋白 $37 \%$, 尿糖 $27 \%$,ウロビリノーダン $30 \%$ であった。さらに これら再検查に和いて, 陽性を示す者について, 精密検 査を行ない，無自觉にあらわれている各人の身体的異常 について倹討してみた。

\section{8. 炉前作業者の視機能及び生化学的調査の検討}

等々力達也, 大森 薰 （古河電工日光電気精銅所）

金属工業に括ける㚸作業は主要作業であって，乙かも それに従事する学働者数も多い，しかしながらこれら学 㗢者はとくに非鉄金属の炉作策に执いては，金属湯面の 直視による，いわゆる感によって各種合金等を鋳造する 場合が多く，従って一般に高年齢の熟練者である。

このよらな炡作業の性質上，赤外線などによる一種の 灼熱性眼障害の括こる可能性，及び金属蒸気あるいは粉 塵による生化学的影響も無視できないと思われる。

筆者等はこれら学働者について, 視機能については, 視力, 視野, 暗点及び眼底所見, 生化学的娭查として血 液及び尿の諸検查を行ない，金属の種類及び金属湯温別 によるこれら諸検查の成績の比較と, 腿所見と生化学的 所見との相互関係について检討し，二，三の知見を得た ので報告する。

\section{9. 某製鉄所における眼科精密検查の総合成績}

妹昆 博（釜石製鉄所病院）

高血圧管理を主眼とし，あわせて視力障害の原因を检 索し, 健康管理強化の基礎資料とすべく, 全従業員に対 乙眼底検查を実施した。検查対象の人員総数は 7588 名で，そのうち受検者は7233名 (95\%)，未受検者 355 名(5\%) の受検成績であった。

1. 視力について：両眼とも健常視力を有するもの は, 正視眼 4255 名, 屈折異常眼 1557 名, 計 5843 名 で，総受検者の $81 \%$ にあたる。1眼の及健常視力を有 するものは, 正視眼 252 名, 屈折異常眼 255 名, 計 507 名で7\%を占めた。1眼の視力が指数以下の者は21名， 兩眼之も視力 0.4 以下の渚は 12 名で，その多くは公傷に 基因する。一般の視力障害の原因は愿折異常に原因する ものが第 1 位で, 角膜疾患, トラコーマが, ほぼ同数と なり第 2 位, これにつぎ䋩・脉絡膜疾患, 硝子体疾患, 視束疾患の順位であった。

2. 色覚について：色覚異常者は総数 281 名，総受検 